\title{
Envisioning the Sicilian-Maltese archipelago: a Braudelian inspired triple-level analysis of a European cross-border region
}

\author{
Francesco Maria Camonita \\ Department of Geography, Autonomous University of Barcelona (UAB), Spain \\ Francescomaria.camonita@uab.cat
}

\begin{abstract}
This article seeks to advance the current debate on the 'archipelagic turn' described by island studies. It does so by answering the call for further analysis of island-to-island relations (Stratford et al., 2011) through applying existing historical methodology with the identification of island movements (Pugh, 2013) between archipelagic islands. Firstly, it proposes the application of an adapted method by combining Fernand Braudel's historical durations (Longue Durée) (1972) with an original attempt of island movements' classification; this is done to conceive a triple-level historical analysis (Long, Medium and Short Term) of islands belonging to archipelagos. Secondly, this article hints at the possibility for island territories inside the European Union to translate archipelagic visions into viable policies by means of European Territorial Cooperation strategies as provided by the European institutional framework. Such arguments are then supported by comparative analysis proving the existence of an archipelago between the islands of Sicily and Malta. In our case study, we both apply the triple-level methodology and suggest that the exploitation of European CrossBorder Cooperation instruments and strategies (such as the Euroregion) could be highly useful for the recovery of a Sicilian-Maltese Archipelago vision.
\end{abstract}

Keywords: archipelagos, cross-border cooperation, Euroregions, islands, Longue Durée, Malta, Sicily

https://doi.org/10.24043/isj.82

C 2019-Institute of Island Studies, University of Prince Edward Island, Canada.

\section{Introduction}

This article seeks to advance the current debate on the 'archipelagic turn' described by island studies. It does so by answering the call for further analysis of island-to-island relations (Stratford et al., 2011) through applying existing historical methodology with the identification of island movements (Pugh, 2013) between archipelagic islands. Firstly, it proposes the application of an adapted method by combining Fernand Braudel's historical durations (Longue Durée) (1972) with an original attempt of island movements' classification; this is done to conceive a triplelevel historical analysis (Long, Medium and Short Term) of islands belonging to archipelagos. Secondly, this article hints at the possibility for island territories inside the European Union 
to translate archipelagic visions into viable policies by means of European Territorial Cooperation strategies as provided by the European institutional framework. Such arguments are then supported by comparative analysis proving the existence of an archipelago between the islands of Sicily and Malta. In our case study, we both apply the triple-level methodology and suggest that the exploitation of European Cross-Border Cooperation instruments and strategies (such as the Euroregion) could be highly useful for the recovery of a Sicilian-Maltese Archipelago vision. Throughout the article, the case study provides a useful testing ground for our methodology while theoretical insights provide context for reinterpreting the SicilianMaltese archipelago area.

In the first section, we build the basis of our methodology inspired by a theoretical framework of archipelago-related theories and historical insights from Braudel's Longue Durée. The following three sections are devoted to each of the three durations proposed for our case study (Long, Medium and Short). Thereafter, we proceed to discuss the application of a 'SicilianMaltese Archipelago' conceptualization over the current Sicilian-Maltese cross-border area. Finally, we draw some necessary conclusions on the implications derived from the article.

\section{Theoretical framework and methodology}

In their contribution to the development of archipelago theories, Stratford et al. (2011) indicate three main dimensions for studying islands: a) islands embedded in their insularity as lands surrounded by water; b) islands in comparative disadvantage with a mainland often exercising territorial jurisdictions and imposing normative values upon them; and c) islands in relation to other surrounding islands (archipelagos), often seen as an alternative disrupting the first two predominant views (Stratford et al., 2011). However, despite the original proposals included in their work, the authors continue to agree with the original claim from Lewis \& Wigen (1997) portraying the Archipelago as one of the least-examined metageographical contexts. This does not necessarily indicate a previous lack of theorization. The early concept of 'Archipelagraphy' as presented by DeLoughrey $(2001,2007)$ already identifies it as an alternative historiography, considering chains of islands as a more appropriate metaphor for reading into island realities. It involves a process of dislocation and de-territorialization, constituting a new viewing platform that perceives them anew (DeLoughrey, 2001, 2007; Stratford et al., 2011, p. 114). A complementary definition also sees the process as an exploration of alternative cultural geographies and alternative performances, representations and experiences of islands (Stratford et al., 2011). Jonathan Pugh (2013) brings the reasoning even further by trying to define the key element shaping archipelagic visions, thus placing an emphasis on how islands act in concert. He benefits from the work of Deleuze and Guattari (1986) to define island movements as "fluid cultural processes, sites of abstract and material relations, of movement and rest, dependent upon changing conditions of articulation or connection" (Pugh, 2013, p. 11). Furthermore, he identifies them as generative and interconnecting spaces of metamorphosis, material practices, culture, and politics.

The final objectives behind such reconfiguration have also been identified by proponents of archipelago conceptualizations. Whether the purpose lies in: a) identifying relational paradigms that transcend the current status quo and unveil the biases of dominant relations (Stratford et al., 2011, p. 124); b) delineating an island community across multiple jurisdictions (Hau'ofa, 1993); or c) developing a collective identity for strengthening 
marketing, branding, exports and the "suggestive" character of a common islands region (Stratford et al., 2011, p. 123), all resolutions ultimately indicate a will to "locate vantage points [for archipelagos] that give one a wider horizon" (Sengupta, 2004, p. 1). Despite the abundance of good intentions and theoretical definitions, however, we claim that there are two gaps in the specialized literature regarding the application of archipelagic visions. More specifically, this research identifies one ex ante and one ex post vacuum in the archipelago conceptualization. First, at ex ante level, it is not clear specifically how island movements should be methodologically identified, assessed and measured in a specific case study. Pugliese (2011) offers a reinterpretation of a previous definition of Brathwaite by quoting 'tidalectics' as the analysis of material, cultural, and psychological island processes. In his words, the analysis of islands' histories and practices can provide new "technologies for un-islanding" (Pugliese, 2011, p. 148). Notwithstanding, proponents of archipelagic studies often prefer to leave ample choice for creativity in new lines of research without considering a specific set of guidelines. Second, at ex post level, the real challenge for academics dedicated to the conceptualization of island-to-island relations lies in the capacity to motivate island actors towards common archipelagic policies. Especially considering the multiple national jurisdictions to which many archipelagos are today exposed, it does not take long to see the hardships involved in empowering local actors towards joint actions for the benefit of all component islands.

On the methodological level, our research goals pointed to a multi-perspective analysis of islands which could combine the many fields characterizing a territory beyond its histoire événementielle (history of events). Investigation regarding pre-existing methodologies soon led to Fernand Braudel's (1972) celebrated work on The Mediterranean. Of relevance were his desire to repair the mid-20 ${ }^{\text {th }}$ century break between history and social sciences and the formal introduction of the concepts of Long, Medium and Short Durations (or Terms) of history as three separate yet intertwining levels of analysis (Canto Mayén, 2012). Indeed, most of the principles associated with his Longue Durée methodology resonate with the goals of archipelago proponents. Longue Durée history allows one to "step outside of the confines of national history and ask about the rise of long-term complexes over many decades, centuries or even millennia" (Armitage \& Guldi, 2015a, p. 222). It is a methodology connected to changing questions of scale by holding the power of persuasion and promoting conversation about social change (Armitage \& Guldi, 2015a, p. 244). The longevity of the theory spawned critical reflections which are also embraced by this research. The rejection of the original Longue Durée vision of history as interlocked in historical and economic cycles and often described as a prison constitutes one such example (Armitage \& Guldi, 2015b, p. 18); so, too, are the dangers presented by the development of 'dirty' Longue Durée studies in the second part of the $20^{\text {th }}$ century by think tanks and NGOs at the service of positivist international institutions. Their impoverished array of historical evidence and broad-gauge conclusions often resulted in oversimplifications disregarded and rejected by historians from the 1960s onwards, rather focusing on 'microhistory' narratives (Armitage \& Guldi, 2015b, p. 28-29). However, this article ultimately agrees with the renewed focus expressed by Armitage and Guldi (2014) on the return of a revived Longue Durée. We adhere to their request for the fusion of short and long durations as a dialogue between past and present while also looking toward the future. We believe in its potential accessibility to non-specialized readers, and that by creating bridges among past and present, it is possible to uncover moments of continuity and rupture. Indeed, 
we carry forward a shared vision of the Longue Durée as a dynamic, flexible, and critical tool to dismantle established narratives and institutions in place (Armitage \& Guldi, 2014).

However, precisely to avoid incurring accusations of 'dirty' Longue Durée, it is important to acknowledge the limitations produced by the crossing of such a historically oriented methodology with island studies. The model hereby proposed is limited in both extension and scope and, as such, will be successful in highlighting certain shared aspects of archipelagos while obscuring other differences. It deliberately focuses on certain typologies of island movements while necessarily ignoring other aspects such as ecology and daily life, which were, indeed, aspects of history with which Braudel himself was deeply concerned. Therefore, in our combination of the Longue Durée with a renewed outlook sought by archipelagic visions (Pugh, 2013, pp. 12-14), the long-term analysis becomes a necessary focus on the geohistorical and geographical conditions of territories throughout their event histories The medium-term one, which is deliberately represented by the alteration of historical cycles of political and cultural dominations shaping islandic populations, is fundamental in the discovery of movements of connection or separation between islands as well as the appreciation of the metamorphosis of island cultures in relation to each other (Pugh, 2013, pp. 14-19). Finally, in the Short-Term analysis, we further test the methodology in relation to a 'short' period by intentionally focusing on the most recent history of the two islands of Sicily and Malta (19452018). This final section also provides essential historical background for our ex post conceptualization.

The revived Longue Durée and new archipelagic outlooks also inspire our desire to pursue solutions in the ex post gap in island studies. In this regard, the research hints at the existence of a window of opportunity for European islands within the framework of the European Union (EU). Discourses regarding different interpretations of neighbouring territories are, in fact, appreciated in the academic literature analyzing European Territorial Cooperation policies and more specifically Cross-Border Cooperation practices (e.g., Popescu, 2008; Noferini et al., 2019). Furthermore, at an institutional level, the EU actively pursues European territorial cohesion by providing funding and policy instruments such as the INTERREG cooperation programmes or by sponsoring joint governance agreements. This consequentially translates into the definition of cross-border regions also acknowledged in the presence of a maritime border. Under this framework, we consider there to be common grounds between the finalities of an archipelagic vision and the creation of cross-border strategies for common development between the EU's bordering islands. Thus, while the primary target of this research is related to methodological advances in the identification of archipelagos as described in the field of island studies, the results of the three-terms analysis may potentially become a roadmap for policymakers in the consolidation of archipelagic visions.

All the above thus justifies the selection of Sicily and Malta as an ideal case study for the application of the proposed methodology. In terms of the necessity for an archipelagic reconfiguration, the design of a Sicilian-Maltese Archipelago can de facto break through the understanding of Sicily as the perpetual 'Italy's Island Other' (Agnew, 2000) while reconnecting Malta outside of its relative isolation as a small and sovereign but resourcelimited island state on the southern periphery of Europe (Cassar et al., 2008). Furthermore, both islands belong to the framework of the EU, hence fulfilling the second criteria necessary for theorization on ex post action. 


\section{Long-term analysis: Sicily and Malta as a Mediterranean archipelago}

The first step of the Long-Term analysis lies in the definition of the physical unit and its island components. Thus, the envisioned area would be constituted by the two main islands of Sicily and Malta while also including the surrounding waters and the smaller island clusters administratively belonging to the two parent islands (the Aeolian, Egadi, and Pelagian islands on the Sicilian side and Gozo and Comino on the Maltese side; see Figure 1). Within the scope of this article, we mainly aim for a revived conceptualization of territorial issues which can break free of traditional grand narratives. This is done in accordance with new trends favouring a more relational view of space rather than fixed territorial containers (Pugh, 2013, pp. 13-14) defined by national boundaries and sovereignty. To complete such a task, we identify two variables in our reasoning about Sicily and Malta: a) general issues as European and Mediterranean islands in a shared geographical location; and b) archipelagic issues borne of territorial proximity.

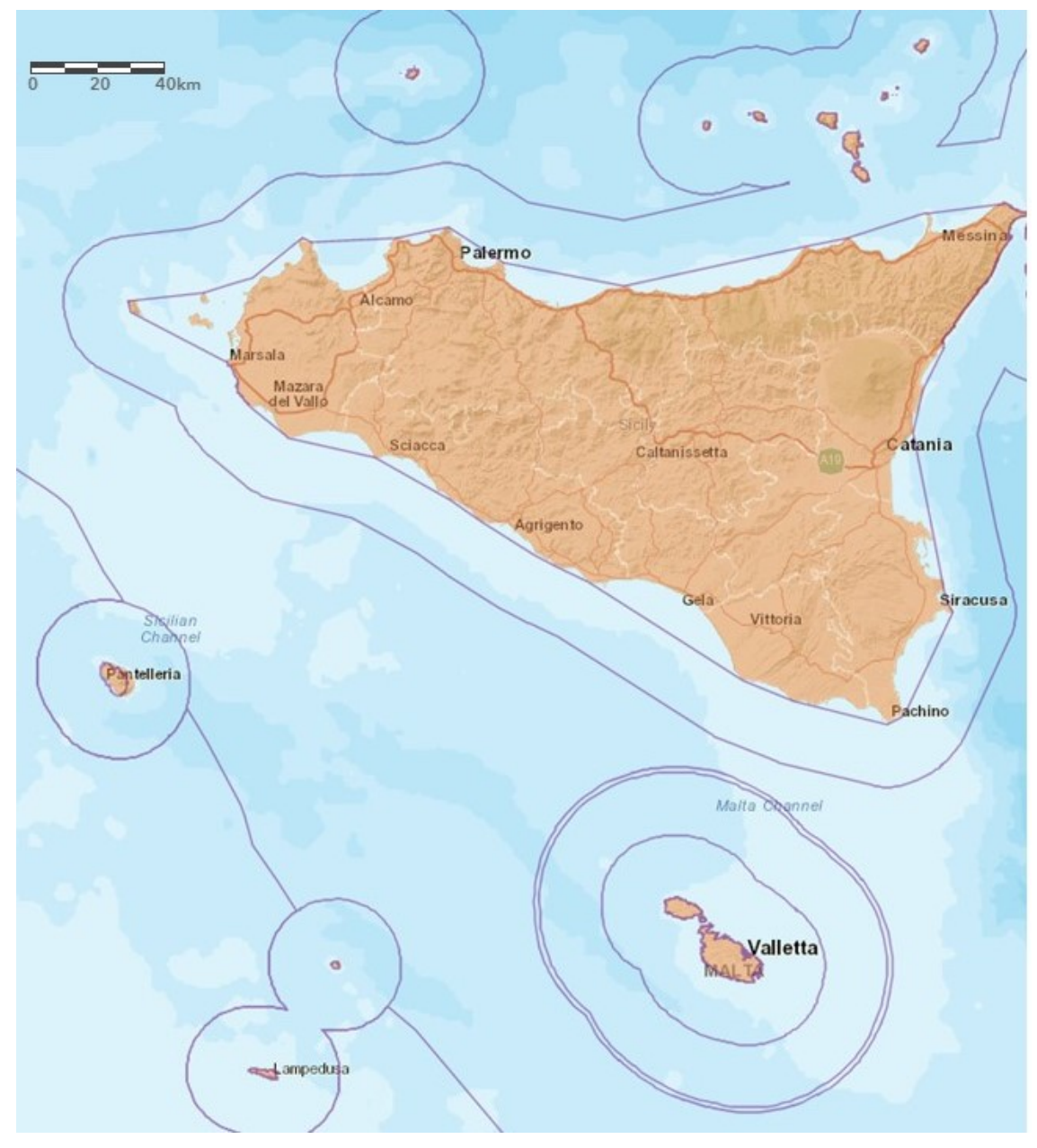

Figure 1: Map of the Sicilian-Maltese Archipelago produced using GIS Software. Source: Own elaboration.

In the general assessment of the two islands, perhaps the most immediate shared feature is found in their belonging to the larger family of Mediterranean islands. From a sociohistorical point of view, Mediterranean islands experienced isolation as a very relative 
phenomenon outside of traditional narratives. Their integration into shipping routes and in the territorial struggles of their time interlocked them in a dual dynamic between either 'archaism or innovation'. Involvement and internationalization through such interactions, as well as their refusal to participate in such dynamics by seeking shelter inland to preserve traditions, became two sides of the same coin. Accordingly, so did their economic markets when considering the capitalist exploitation of islands by foreign powers but also the opportunity of making a reputation through dominating large Mediterranean trade segments (Braudel, 1972, pp. 148-157; cf. Lopasic, 2001).

Beyond history, however, modern institutional and academic literature has focused much on sets of common issues deriving from anthropogenic impacts on the landscape of Mediterranean islands. In a broad categorization, these are related as much in terms of exploitation of natural resources (e.g., agricultural landmarks, land commercialization and expanding urbanization, excessive water demands) as they are to contemporary pressures related to globalization and neoliberal capitalism (e.g., pressure from tourism but also the need for modern infrastructure and services to improve trade and general accessibility) (Papayannis \& Sorotou, 2008, pp. 85-94). Further insight is provided by studies funded by the EU. In addition to clear imbalances in of all Southern Europe's islands in terms of economic performance relative to comparable mainland regions, all European islands deal with similar issues regarding: a) vulnerability to climate change and environmental threats (Dodds \& Kelman, 2008; Nichols \& Hoozemans, 1996); b) poor education levels (leading to difficulty in transitioning from traditional activities to more innovation-based activities) (EUROISLANDS, 2013); and, most significantly, c) the perverse effects of insularity. Due to geographic limitations, their economic attractiveness is always lower when compared to the mainland, and this translates into further disadvantages: d) the impossibility of creating functional economies of scale (impeding the development of greater accessibility and lower transport costs); e) the inability to profit from agglomeration externalities; and, finally, f) the prevention of conversion to sustainable development practices (Briguglio, 1995; Cordina \& Farrugia, 2005; EURISLES, 2002; EUROISLANDS, 2013; Moncada et al., 2010; Musotto, 2007).

While it is true that these issues may represent an obstacle to development, a growing strand of literature has sought to counter arguments on islands' disadvantages by reshaping development-oriented definitions of concepts such as 'vulnerability' and 'resilience' (Kelman, 2019). By embracing new views on relationality and empowering discourses, island scholars rightfully warn against excessive prejudice in policymaking and suggest alternative ways of interpreting island realities (Baldacchino, 2018; Chandler \& Pugh, 2018). When considering further interpretations which go beyond the island development debate, our case study provides interesting elements for the elaboration of an alternative outlook on the SicilianMaltese Archipelago. For example, the geographic limitations and lack of hinterlands of the small island of Malta are today compensated by its national sovereignty and its average economic performance vis-à-vis other EU member states. In turn, Sicily's structural issues as an economically lagging island region are a product of its history and are only partially due to its condition of insularity. This becomes rather clear when considering its strong proximity to the Italian peninsula, the richness in natural resources derived from its large size, and its special statute for political autonomy (which could, in principle, allow for greater policy intervention). Beyond individual differences, therefore, it is possible to appreciate several commonalities in island issues affecting the Sicilian-Maltese Archipelago space (see Table 1). 
In relation to territorial proximity, an initial geographical comparison would only seem to underline differences rather than commonalities between two islands separated by such narrow distance (the approximately $92 \mathrm{~km}$ strait of sea called the Malta Channel). With its $25,708 \mathrm{~km}^{2}$, Sicily is easily the largest island in the Mediterranean, and its geomorphology allows for a diversified weather regime defined by its mountains, rivers, plains, hills, and long stretches of accessible coastline. The opposite is true for the much-smaller Malta. The Maltese archipelago has a total land area of just $316 \mathrm{~km}^{2}$, and its mostly hilly terrain is accompanied by shallow valleys and sheltered natural harbours immersed in a semi-arid climate (Bonanno, 2006, pp. 27-28). However, it is due to such differences that a primordial connection is spawned between the two territories in terms of a territorial dependency of the smaller upon the larger. The state of dependency has been shifting over the centuries due to precise political and historical conditions (see following sections). However, already in prehistoric times, geological evidence suggests that Sicily and Malta were geographically connected by marine regression, resulting in much shared flora and fauna (Cassar et al., 2008, p. 304). Many accounts of Sicilian history remain silent on its relationship with Malta, yet no Maltese reference work can escape narrations of the economic and mobility relationships of the two islands' inhabitants. Even in recent times, European strategies lay the groundwork for a Sicily-Malta submarine interconnector granting energy supply to the small island state (4cOffshore, 2015). Furthermore, considering the recent Eurozone crisis, a reverse trend has been developing in which many Sicilians transfer to the smaller adjacent island to invest in new (mostly food service) businesses in a more favourable economic environment (The Independent, 2015).

When considering more strategic arguments, both Sicily and Malta are identically-yet individually -identified as crossroads that traditionally separates the East and the West as well as the Southern Mediterranean and the Northern Mediterranean (e.g., Blouet, 1997, p. 11; Braudel, 1972, p. 133; Goodwin, 2002, p. 27). Furthermore, it would be conceptually false to claim that the strategic importance of these islands has been lessened by globalization. For example, the European TEN-T transport strategy identifies the presence of a 'Motorway of the Sea of South-West Europe', which includes passage through the Malta Channel (European Commission, 2018a). At the same time, in the contested definition of spatialities, both Sicily and Malta have seen themselves identified as 'Southern Gates' at the periphery of the EU, which have become a hotspot in the EU's 'migration crisis' and spawned an intense debate between national political authorities. There are thus numerous shared attributes within the envisioned Sicilian-Maltese Archipelago space (Table 1). Back to the field of island studies, Stratford et al. (2011, p. 118) coherently mention the risks of erasure faced by archipelagic visions through individual descriptions of islands that reduce them to single entities. In the case of the Sicilian-Maltese Archipelago, this process is noticeable due to the historical shifts in policy level for regional issues at the national and later the European scale. We will refer to such episodes of rupture in archipelagic relations in the following sections. 
Table 1: Long-term analysis of multiple common territorial issues for a Sicilian-Maltese Archipelago area. Source: Own elaboration.

\begin{tabular}{|c|c|c|}
\hline & $\begin{array}{l}\text { Mediterranean/European Island } \\
\text { Issues (Geographical Location) }\end{array}$ & $\begin{array}{l}\text { Common } \\
\text { Archipelagic Issues } \\
\text { (Proximity) }\end{array}$ \\
\hline $\begin{array}{l}\text { Autonomous } \\
\text { Island Region of } \\
\text { Sicily (Italy) }\end{array}$ & $\begin{array}{l}\text { - Autonomous island region of } \\
\text { Italy } \\
\text { - Largest island in Mediterranean, } \\
\text { resource rich, varied landscape } \\
\text { - Reduced insularity effect } \\
\text { (proximity to mainland Italy) } \\
\text { - Objective } 1 \text { region of Cohesion } \\
\text { Policy } \\
\text { (lagging region in the EU } \\
\text { framework) }\end{array}$ & 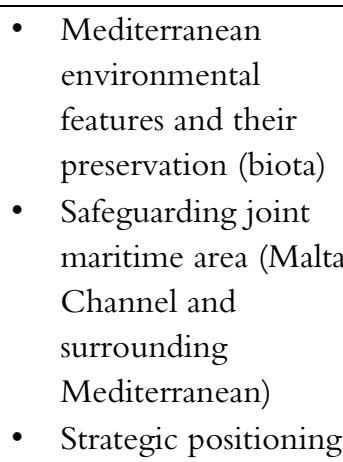 \\
\hline $\begin{array}{l}\text { Sicilian-Maltese } \\
\text { Archipelago }\end{array}$ & $\begin{array}{l}\text { - Leading roles and multiple } \\
\text { commonalities in Mediterranean } \\
\text { history } \\
\text { - Vulnerability to climate change } \\
\text { and environmental threats } \\
\text { - Geographic location far from } \\
\text { European functional economies } \\
\text { of scale (impossibility to tag along } \\
\text { with agglomeration externalities) } \\
\text { - Poor education levels } \\
\text { - Difficulty achieving sustainability }\end{array}$ & $\begin{array}{l}\text { at the centre of } \\
\text { Mediterranean Sea } \\
\text { (economic trade } \\
\text { routes) } \\
\text { - Strategic energy } \\
\text { connections } \\
\text { (electricity, gas, etc.) } \\
\text { of the smaller to the } \\
\text { larger island's power } \\
\text { grids } \\
\text { Southern periphery }\end{array}$ \\
\hline $\begin{array}{l}\text { Island Republic } \\
\text { of Malta }\end{array}$ & $\begin{array}{l}\text { - Sovereign island state } \\
\text { - Small, limited natural resources, } \\
\text { unvaried landscape } \\
\text { - Classic insularity effect } \\
\text { - One of the best average } \\
\text { economies of the Mediterranean } \\
\text { EU }\end{array}$ & $\begin{array}{l}\text { gateway to the EU } \\
\text { (relationship with } \\
\text { Mediterranean non- } \\
\text { EU countries, } \\
\text { refugee issues) } \\
\text { - Mediterranean } \\
\text { cultural heritage } \\
\text { - Cross-border direct } \\
\text { economic and } \\
\text { population flows }\end{array}$ \\
\hline
\end{tabular}

\section{Medium-term analysis: common origins but different destinies in the Sicilian- Maltese archipelago}

Let us now turn our attention to the medium-term analysis of the two island components. In this second section, we proceed to classify the histories of Sicily and Malta according to the cycles of foreign dominations that have impacted the two territories at different times. In advance of the analysis, it must be acknowledged that many historical sources focus exclusively on Italo-Maltese relations at the national level. Original research on Sicilian-Maltese relations is rare, and often refers to partial timelines or specific events in their joint history (e.g. Bonanno \& Militello, 2008). This has led to two separate reconstructions, elaborated through some of the most distinctive accounts of the two islands. Eventually, we decided to mainly refer to research that led to the identification of island movements by granting deeper insight into the material, cultural, and psychological processes of each unit. Thus, having consulted 
a variety of works on the history of Sicily (including Correnti, 2002; Di Matteo, 2006; Hamel, 2011; Renda, 2003), we eventually selected Mack Smith and Finley (1968) and Schneider and Schneider (1976) as main references for the island region. Likewise, in the field of Maltese history, the works of Blouet (1997) and Goodwin (2002) were also selected out of the exploration of a larger collection of anthologies (Cassar, 2000; Castillo, 2005; Murray Ballou, 1893). Finally, we decided to stop the timeline of the medium-term analysis at the time of creation of the Maltese state. This is done by explicitly considering the time framework between the consolidation of a Sicilian autonomous region (1946) and the declaration of independence of the Maltese archipelago (1964) as the apex of rupture in archipelagic relations between the two components.

The analysis derived from the observation of the comparative timeline allows us to divide the resulting relational history of the Sicilian-Maltese Archipelago into two main phases. Specifically, we classify an Age of Continuity (c. 5000 BC-AD 1524) embedded in mutual relations and developed through the presence of common foreign dominations as opposed to an Age of Rupture (1524-1964) with diminished relations and different dominations of the two islands. Like Baldacchino (2015, pp. 89-90), we identify the main moment of rupture between the two ages as the decision by Charles V of Spain to grant Malta to the Knights of St John. This religious yet military-oriented Order had a strong heritage of heroic chivalry from the time of the Crusades and thus had the respect (and wealth) of many powerful European families. The request for new headquarters to the Spanish ruler was a result of the Order's expulsion from the island of Rhodes after a Turkish siege. The monarch therefore saw an opportunity to donate a small yet symbolically important territory for the Knights to administer independently, although officially under the Kingdom's sovereignty. Following a well-established trend known to scholars of island studies, the jurisdictional rupture of the larger Kingdom of Sicily was decided by an external and distant ruler, setting the political trajectory of the two islands on two separate tracks.

In addition to this event, we claim that there have been up to three historical moments within the Age of Rupture, which managed to distance the components of the archipelago even further. These are: a) the aforementioned granting of Malta to the Knights of the Order of St John by Charles V; b) the British presence in the Mediterranean through their subsequent occupation of Malta from 1800 onward (and the failure to introduce a new constitutional order in Sicily during the same period); and c) the establishment of a Maltese sovereign island state and the institutionalization of Sicily as an autonomous region of Italy in the mid- $20^{\text {th }}$ century.

We endeavoured further elucidation by compiling a list of relational features within the histories of the two islands. As part of the proposed methodology, we classified island movements according to five typologies: a) presence of foreign dominations; b) economic features; c) culture and identity; d) society and social class; and e) political culture and regimes. Such classification work was inspired by the aforementioned work of Schneider and Schneider (1976) in their multi-perspective analysis of Sicilian history. Finally, in accordance with each typology, across all the historical ages, we distinguished the shared features in the history of the two islands (Movements of Connection) and the specific events or processes that developed only in either one of the two sides (Movements of Separation). The resulting schematization can be observed in Table 2 below. 
Table 2: Medium-term analysis of Movements of Connection and Separation between the histories of Sicily and Malta. Source: Own elaboration.

\begin{tabular}{|c|c|c|}
\hline & Movements of Connection & Movements of Separation \\
\hline $\begin{array}{l}\text { Foreign } \\
\text { Dominations }\end{array}$ & $\begin{array}{l}\text { Age of Continuity (5.000 BC-ca. AD } \\
\text { 1530): Sicani and Siculi, Phoenicians, } \\
\text { Carthaginians, Romans, Byzantine, } \\
\text { Arabian, Norman, Swabian, Angevin, } \\
\text { Aragonese, Spanish }\end{array}$ & $\begin{array}{l}\text { Age of Rupture (AD 1530-AD 1964): } \\
\text { Spanish, Bourbon, Italian (Sicily); Order of } \\
\text { the Knights of Saint John, French, British } \\
\text { (Malta) }\end{array}$ \\
\hline $\begin{array}{l}\text { Economic } \\
\text { Features }\end{array}$ & $\begin{array}{l}\text { - Common lack of historical industrial } \\
\text { activities until } 19^{\text {th }} \text { century } \\
\text { - Archipelagic islands as common } \\
\text { trade routes at heart of the } \\
\text { Mediterranean } \\
\text { - Wealthy elites, the Church, and } \\
\text { later the government as largest } \\
\text { employers } \\
\text { - Strong migration waves to escape } \\
\text { the islands' conditions (Age of } \\
\text { Rupture) } \\
\text { - Cross-border mobility and inter- } \\
\text { island trade flows }\end{array}$ & $\begin{array}{l}\text { - Differences in natural resources, historical } \\
\text { dependence of the smaller upon the } \\
\text { larger (until late Age of Rupture) } \\
\text { - Sicily mainly dedicated to agricultural } \\
\text { sector throughout its history, in a } \\
\text { capitalist exploitation system (latifundism) } \\
\text { - In Age of Rupture, Malta is economically } \\
\text { strengthened in trade both under the } \\
\text { Knights (goods and slaves) and through } \\
\text { the British shipyard industries }\end{array}$ \\
\hline $\begin{array}{l}\text { Culture \& } \\
\text { Identity }\end{array}$ & $\begin{array}{l}\text { - Mediterranean culture traits forged } \\
\text { by the common dominations in the } \\
\text { Age of Continuity } \\
\text { - Strong Christian influence since } \\
\text { Medieval times } \\
\text { - Common 'islander' awareness of the } \\
\text { particularity of their own insular } \\
\text { conditions }\end{array}$ & $\begin{array}{l}\text { Language: Semitic Maltese and English } \\
\text { vs. Latin Sicilian and Italian. Yet strong } \\
\text { influence in the vocabulary from the } \\
\text { larger island to the smaller. } \\
\text { - Malta: mix of Mediterranean culture with } \\
\text { Anglo-Saxon traditions }\end{array}$ \\
\hline $\begin{array}{l}\text { Society \& } \\
\text { Social Classes }\end{array}$ & $\begin{array}{l}\text { - Traditional and Mediterranean } \\
\text { societies (cultural codes, 'honour' as } \\
\text { fundamental value, concept of } \\
\text { shame, gender segregation, } \\
\text { 'friendship' networks) } \\
\text { - Small number of elites ruling over } \\
\text { the masses } \\
\text { - Petit bourgeoisie incapable of } \\
\text { - } \text { prompting major cultural change } \\
20^{\text {th }} \text { century) }\end{array}$ & $\begin{array}{l}\text { Malta: foreign dominations from the Age } \\
\text { of Rupture lead to better treatment of the } \\
\text { Maltese; vassalage to the Knights } \\
\text { (employing slavery for exploitation) and } \\
\text { progressive administrative autonomy } \\
\text { through the British Commonwealth } \\
\text { - Sicily: During the late Age of Rupture, } \\
\text { manifestation of the Mafia phenomenon }\end{array}$ \\
\hline $\begin{array}{l}\text { Political } \\
\text { Culture \& } \\
\text { Regimes }\end{array}$ & $\begin{array}{l}\text { - Traditionally conquered lands at the } \\
\text { service of foreigners ('servants and } \\
\text { masters') } \\
\text { - Common administration throughout } \\
\text { the Age of Continuity: viceroys and } \\
\text { foreign administrators }\end{array}$ & $\begin{array}{l}\text { - Malta: evolution in political culture } \\
\text { through progressive political and } \\
\text { administrative autonomy under the } \\
\text { British, later opportunity for } \\
\text { independence } \\
\text { - Sicily: 'Gattopardian' elitist scenario until } \\
\text { institutionalization of the Sicilian } \\
\text { autonomous region }\end{array}$ \\
\hline
\end{tabular}

The great majority of identified features support our initial distinction between an Age of Continuity and an Age of Rupture. During the first part of the Sicilian-Maltese archipelago's history, the presence of almost every Mediterranean-exploring civilization on both islands 
produced resonating effects on all further typologies of Movements of Connection. Table 2 is thus instrumental in delivering the vision of an archipelago accustomed to the service of foreign administrators. It helps highlight the profile of traditional Mediterranean island societies developing under the same masters and through the deep influence of the Christian church. At the same time, it shows the impact that different political regimes have had over the economic and social development of the two territories.

However, the schematization is equally effective at illustrating the Movements of Separation between Sicily and Malta. It considers significant differences occurring even during the Age of Continuity. Fitting examples include the incomplete Latinization process in Malta due to a lack of real strategic interest from the Roman Empire (Blouet, 1997), as well as the geographical limitation of a small archipelago without agricultural potential, which also led to the avoidance of latifundism - that is, exploitation by large-scale agricultural actors. Most importantly, the movements of separation reinforce our argument regarding the rupture points in archipelagic relationships. Firstly, the arrival of the Knights of the Order of St John meant that Malta achieved a new level of economic prosperity economically fuelled by the wealth of European nobility. Secondly, despite the continued relationship of vassalage to foreign masters, the Maltese islands were discovering a new level of independence, which lifted their status relative to the larger adjacent island (Goodwin, 2002). Thirdly, the annexation of Malta by the British Empire largely refers to a political-cultural evolution process developed through progressive autonomy at the representative and administrative levels. The resulting mixture of Maltese and Mediterranean culture with Anglo-Saxon traditions would prompt deep changes, in stark contrast with a Sicilian counterpart locked in a 'Gattopardian' elitist scenario, itself dominated by an early capitalist and exploitative system (Mack Smith \& Finley, 1968; Schneider \& Schneider, 1976). Such considerations are also reinforced by recent research on patterns of island governance tied to their territorial history. Warrington and Milne's (2018) classification accounts for Malta being a fitting example of a foreign-protected fortress island while Sicily's despoliation at the hand of predatory elites depicts it as an archetypal fief. Eventually, the evolution of historical processes would lead to Sicily's annexation by Italy as an island region (1861) because of intellectual and military involvement in the campaign for Italian unification during the $19^{\text {th }}$ century and to the acquisition of special administrative autonomy following the turmoil of the Second World War (1946). Malta, instead, would maintain its British status throughout the ensuing global conflicts up until the declaration of independence, in part due to the process of decolonization (1964).

\section{Short-term analysis: separate archipelagos heading for a common European framework}

As a final step in the proposed methodology, we now direct our attention to the most recent history of the two islands. We do so by establishing the period between 1945 and 2018 as the focus of our Short-Term analysis. Indeed, the overlap with the end of the Medium-Term is intended to emphasize the consequences that the third rupture point in archipelagic relations brings to the future development of the two islands: the establishment of different political and administrative systems represented the pursuit of very separate territorial and strategic agendas for the two islands. For Sicily, this has meant officially embracing its entrance into the realm of regional politics with a special autonomy statute within the Italian state. But it is 
Malta that has experienced the biggest shift in territorial competences through universal recognition of sovereignty and entry into the realm of international relations.

The deeper implications behind the two political statuses required a corresponding adaptation of the short-term analysis' structure itself. As hinted at in the methodological explanation, we distanced ourselves from Braudel's idea of 'short-term history' as the succession of quick events (Canto Mayén, 2012) and from merely producing two separate timelines outlining key events in Sicily's and Malta's histories. Instead, we chose to adapt the scope of the analysis for the purpose of identifying further island movements in our case study within a relatively 'short' timeframe. This was practically done by adapting the classification scheme proposed in the medium-term analysis. Firstly, we retained most of the island movement typologies identified earlier, but we replaced the foreign dominations occupying the two islands with the relationship between the island components and European institutions. Secondly, the diversity expressed by the two political statuses imposed a larger representation of the Movements of Separation by filtering the main features of their respective regional and national histories. To do so, we relied both on the sources already employed in the previous section and further literature dedicated to the history of the two islands (for Sicily, Leonardi, 2016; Menighetti \& Nicastro, 2002; for Malta, Camonita, 2019; European Commission, 2018b; Harwood, 2014.). Thirdly, the table also provides a column identifying the Movements of Connection encountered during the selected period, although their recollection followed a different methodological approach and further consideration needs to be devoted to this section of the analysis.

The diverse focus on the Movements of Connection was mainly due to the varying scales of relations between the two island territories. On a European level, we already identified direct territorial exchanges stimulated by joint membership into a common supranational framework (e.g., infrastructural projects shown in the long-term analysis or the INTERREG cross-border cooperation programme). On a national level, in the table we referred to the presence of state-level relations such as the Italo-Maltese cooperation protocol of 1980 having significant economic consequences for Malta. However, many shared issues affecting the two islands (i.e., the recent migration crisis) are policy-dependent on the national dialogue between Rome and Valletta and are currently beyond Sicilian competences in our archipelagic conceptualization. Finally, at the regional level, the identification of modern cross-border flows between the two islands' inhabitants still represents uncharted territory for academia. To the best of our knowledge, only limited statistical attempts have been made by the INTERREG operational programme. Even then, the data available mainly consisted of territorial statistics regarding the cross-border area involved (Italy-Malta INTERREG, 2015), thereby excluding any qualitative attempt to identify a list of relevant cross-border issues. Many of these, however, are encountered in the everyday experience of practitioners of Siculo-Maltese relations. Such information was recently acquired through the interviewing of public and private stakeholders carried out as part of a larger research fieldwork dedicated to Sicily-Malta cross-border cooperation and the experience of the 2007-2013 INTERREG programme. For the purposes of the present article, we took the opportunity to include such additional information in the general analytical framework based upon secondary sources.

Finally, it is important to underline that the schematization represents a first attempt at classifying island movements between the two islands in accordance with a defined typology and within a triple-level analysis methodology. As such, on the one hand, we indicate the originality of the work and the lack of previous studies in multisectoral relational analyses of 
Sicily and Malta in recent times. On the other hand, this research also acknowledges the limitations both in space and content on performing a more in-depth comparative history of the archipelagic components. Our proposed grid containing a selection of main features can be but a starting point of reference. However, the grid still provides essential historical background and relevant cross-border arguments for our ex post conceptualization in the following section of the paper. Thus, the results of the schematization can be consulted in Table 3 below.

Table 3: Short-term analysis of Movements of Connection and Separation between Sicily and Malta (1945-2018). Source: Own elaboration.

\begin{tabular}{|c|c|c|c|}
\hline & \multicolumn{2}{|c|}{$\begin{array}{l}\text { Movements of Separation (selected examples from } \\
\text { sectoral histories of the two islands) }\end{array}$} & \multirow{2}{*}{$\begin{array}{l}\text { Movements of Connection } \\
\text { (cross-border issues) }\end{array}$} \\
\hline & $\begin{array}{l}\text { Autonomous Region of } \\
\text { Sicily }\end{array}$ & Sovereign State of Malta & \\
\hline $\begin{array}{l}\text { Economic } \\
\text { Features }\end{array}$ & $\begin{array}{l}\text { - Historically an } \\
\text { economically lagging } \\
\text { region of Southern Italy } \\
\text { ('Mezzogiorno' debate) } \\
\text { - 'Modernization without } \\
\text { development' process } \\
\text { for Sicily (lack of } \\
\text { endogenous } \\
\text { development) } \\
\text { - Historical dependence } \\
\text { on national public } \\
\text { spending and } \\
\text { extraordinary measures } \\
\text { 1950s-1960s: } \\
\text { investments in heavy } \\
\text { refinement industries } \\
\text { (petrochemicals) and } \\
\text { agriculture } \\
\text { 1970s onwards: surge in } \\
\text { tertiary sector and public } \\
\text { sector activity } \\
\text { 1970s-1980s: progressive } \\
\text { economic privatization } \\
\text { - Strong investment } \\
\text { stimulated by European } \\
\text { funding } \\
\text { 2008 Eurocrisis: high } \\
\text { unemployment and } \\
\text { public debt }\end{array}$ & $\begin{array}{l}\text { 1950s-1960s: UK's } \\
\text { responsibility in } \\
\text { reconstructing and } \\
\text { diversifying the economy } \\
\text { - Post-independence, } \\
\text { British rental of military } \\
\text { facilities until } 1979 \\
\text { (despite political clashes } \\
\text { in 1970-1972) } \\
\text { - Strong industrial tradition } \\
\text { in shipyards, yet a state- } \\
\text { sustained economy } \\
\text { 1980s: Italo-Maltese } \\
\text { protocol (new financial } \\
\text { grants) } \\
\text { 1990-2004: } \\
\text { Europeanization of } \\
\text { Maltese economy } \\
\text { (privatization, public } \\
\text { sector reform, etc.) } \\
\text { Post-EU accession: } \\
\text { Cohesion policy funding } \\
\text { Modern investments in } \\
\text { financial services (post- } \\
\text { EU accession) } \\
\text { Quick recovery from } \\
\text { Eurozone recession, } \\
\text { dynamic and growing } \\
\text { economy. Yet small size } \\
\text { and limited resources. }\end{array}$ & $\begin{array}{l}\text { - Fishermen's encounters } \\
\text { and informal coordination } \\
\text { in the Malta Channel } \\
\text { - Commercial rivalry } \\
\text { between boatyards and } \\
\text { yacht repair services (unfair } \\
\text { competition from Sicily) } \\
\text { - Tourism competition } \\
\text { between the two islands. } \\
\text { (Maltese exploitation of } \\
\text { Sicilian heritage as } \\
\text { excursion packages) } \\
\text { - Cruise tourism (both } \\
\text { islands on Mediterranean } \\
\text { routes) } \\
\text { Historical retail tourism of } \\
\text { Maltese to Catania (Sicily) } \\
\text { - Strong Maltese reliance on } \\
\text { Sicilian agri-food sector } \\
\text { - Post-2008 factor: Increased } \\
\text { migration tendency of } \\
\text { Sicilians to Malta } \\
\text { Regular transportation } \\
\text { systems between the two } \\
\text { islands ('Catamaran' ferry } \\
\text { service, daily flights) }\end{array}$ \\
\hline
\end{tabular}




\begin{tabular}{|c|c|c|c|}
\hline $\begin{array}{l}\text { Culture \& } \\
\text { Identity }\end{array}$ & $\begin{array}{l}\text { - Mass education and mass } \\
\text { media (mostly television) } \\
\text { - 'Italianization' of Sicily } \\
\text { from 1960s onwards } \\
\text { - Bilingualism (Italian as } \\
\text { official language, Sicilian } \\
\text { recognised only as local } \\
\text { dialect) }\end{array}$ & $\begin{array}{l}\text { - Strong Maltese national } \\
\text { feeling after WWII (further } \\
\text { consolidating after } \\
\text { independence) } \\
\text { - 'European' identity debate: } \\
\text { cultural crossroads between } \\
\text { North Africa and Europe } \\
\text { - Bilingualism } \\
\text { (Maltese/English). Italian } \\
\text { no longer official language, } \\
\text { yet some knowledge } \\
\text { among population }\end{array}$ & $\begin{array}{l}\text { - Cross-border reception of } \\
\text { Italian media in Malta } \\
\text { (cinema, television, music) } \\
\text { - Presence of Maltese and } \\
\text { Italian cultural associations in } \\
\text { each other's territories } \\
\text { - Existence of common Italian } \\
\text { and Maltese family names } \\
\text { - Persisting presence of } \\
\text { Italian/Sicilian vocabulary in } \\
\text { modern Maltese } \\
\text { - Common Mediterranean } \\
\text { cultural traits: values (family, } \\
\text { friendship, honour) and } \\
\text { conservative attitudes } \\
\text { (gender discrimination, } \\
\text { clientelism, religious beliefs) }\end{array}$ \\
\hline $\begin{array}{l}\text { Society \& } \\
\text { Social } \\
\text { Classes }\end{array}$ & $\begin{array}{l}\text { - Lack of historical } \\
\text { bourgeoisie } \\
\text { - Legacy of a traditional, } \\
\text { non-entrepreneurial } \\
\text { aristocracy } \\
\text { - 1950s onwards: middle- } \\
\text { class shows mistrust of } \\
\text { partnerships and private } \\
\text { investment } \\
\text { - Consolidation of Mafia } \\
\text { phenomenon } \\
\text { - 'No future' society, } \\
\text { stimulating migration }\end{array}$ & $\begin{array}{l}\text { - Sensitivity to demographic } \\
\text { changes (small size and } \\
\text { limited resources) } \\
\text { - Modern and proactive } \\
\text { society } \\
\text { - Acknowledged as a good } \\
\text { strategic partner, reasonable } \\
\text { and willing to achieve } \\
\text { results in joint ventures }\end{array}$ & $\begin{array}{l}\text { - Hints of cross-border } \\
\text { criminal networking (Mafia } \\
\text { connections to Malta) } \\
\text { - Persisting migrations of } \\
\text { islanders to other countries } \\
\text { (mainly 1950-1980) } \\
\text { - Slow but progressive } \\
\text { secularization of civil society }\end{array}$ \\
\hline $\begin{array}{l}\text { Relations } \\
\text { with } \\
\text { European } \\
\text { Institutions }\end{array}$ & $\begin{array}{l}- \text { Sicily automatically } \\
\text { joining the EC as part of } \\
\text { Italy (founding country in } \\
\text { 1957) } \\
\text { - 'Objective 1' territory of } \\
\text { the EU's Cohesion policy } \\
\text { regional programme } \\
\text { - Strong set of investments } \\
\text { stimulated by the } \\
\text { European Regional } \\
\text { Development Fund } \\
\text { - Long-term obstacles in } \\
\text { managing and spending of } \\
\text { EU funds }\end{array}$ & $\begin{array}{l}\text { - 1970: Initial agreement } \\
\text { EC-Malta and Malta } \\
\text { - 1980s onwards: national } \\
\text { debate about entry in the } \\
\text { EU } \\
\text { - 1990: Maltese formal } \\
\text { application to the EC } \\
\text { (during Italian presidency } \\
\text { of the EU Council) } \\
\text { - 1990-2004: Fulfilment of } \\
\text { criteria for EU accession } \\
\text { (structural reforms) } \\
\text { - 2003: Referendum for EU } \\
\text { accession (90\% turnout) } \\
\text { - 2004: Effective entry } \\
\text { during the EU 'Eastern' } \\
\text { enlargement } \\
\text { - Strategic exploitation of } \\
\text { EU funding and new } \\
\text { geopolitical relevance }\end{array}$ & $\begin{array}{l}\text { - } 2004 \text { onwards: Sicily and } \\
\text { Malta both in the EU } \\
\text { - 2004: Establishment of an } \\
\text { INTERREG CBC } \\
\text { programme } \\
\text { - Participation in joint } \\
\text { ventures (i.e. gas/electricity } \\
\text { projects) } \\
\text { - 2011-2012: First attempt to } \\
\text { establish political CB } \\
\text { governance structures } \\
\text { - Italy (1999) and Malta } \\
\text { (2008) both adopting the } \\
\text { Euro currency }\end{array}$ \\
\hline
\end{tabular}


The observation of the short-term analysis initially confirms our previous considerations regarding a final apex in the rupture of archipelagic relations between Sicily and Malta. This is most evident in the very different political and economic choices pursued by each island through their respective roles in the current international system. Sicilian history reveals a troubled path in its quest for regional development as an autonomous administrative region within the Italian state. It confirms the structural presence of a "modernisation without development" process (Schneider \& Schneider, 1976) incapable of producing endogenous stimulus of the island's own potential. The process has been further aggravated by the presence of 'nationalized regional politics' (often incapable of producing solutions to regional issues) and a general political instability represented by continuous shifts in regional governments (currently reaching 59 governments in 72 years of autonomy) (Menighetti \& Nicastro, 2002). On the other side of the archipelago, Maltese history instead sets the example of a self-aware island state with national institutions that have demonstrated great skill in diplomacy in arranging international agreements while maintaining an official state of neutrality. Both British and Italian financial grants have also contributed to the slow but steady progression of its state-driven economy, one which would become solid enough to sustain the evolution in the 1990s toward neoliberal regimes indicated by requirements for EU accession (Camonita, 2019; Harwood, 2014). Political and economic features are also tightly intertwined with developments in the two islands' societies and their own cultures. Beyond the consolidation of the two separate national identities and their official languages, the analysis reveals traces of opposing trends in inhabitants' attitudes and concerns. This is also accompanied by the underlying of important problematics such as Sicily's Mafia phenomenon and Malta's demographic sensitivity.

Notwithstanding, the analysis also clarifies that the presence of a stable national border between the two islands must not be misconstrued as an interruption of island Movements of Connection. Quite the opposite, the combined methodological analytical work and field research data permits the production of one of the first listings of modern cross-border issues between the two islands. All the island movement typologies include arguments suggesting further cross-border cooperation either for strengthening existing ties (e.g., European, political, cultural) or for resolving existing frictions (e.g., economic, social, political).

Important differences are also encountered in the separate relations of the two islands with the process of European integration. As an island region belonging to one of the six founders of the European Economic Community, Sicilian presence within the European framework was never really in doubt. Instead, the island is often highlighted as a perpetual top-priority 'Objective 1' territory, reaping development aid since the beginnings of the EU's cohesion policy regional programmes. Such interventions have often produced tangible advances in regional development, but the specialized literature still acknowledges the numerous obstacles provided by a general lack of European identity and strategy coupled with crippling and inefficient bureaucracy (Leonardi, 2016). On the other side of the archipelago, however, the Maltese islands deliberately pursued a rather different path of Europeanization. This would only be achieved after a post-Cold War internal debate leading to either a 'Switzerland in the Mediterranean' scenario of neutrality or the final assertion of a European identity proved by membership of the EU club. However, in opposition to Sicily's passive acceptance of the European framework, we here emphasize the positive role that the 
Europeanization identity debate and the consequential structural reforms brought as a chance for Malta to achieve both modernization and development. The final accession to the EU granted the Maltese the political opportunity to establish a strong identity and a long-term strategy for their nation. Finally, it is interesting to note that the analysis of the two islands' relations with European institutions brings to the debate both Movements of Separation in the archipelago (e.g., two separate Europeanization experiences) and Movements of Connection represented by the revival of direct territorial relations between Sicily and Malta (e.g., joint infrastructure projects or the cross-border cooperation program).

\section{The Sicilian-Maltese archipelago as a European cross-border region}

Moving beyond the methodology presented above, the analysis of the three terms can be further developed by outlining the different archipelagic configurations experienced by the two islands. The Age of Continuity would correspond to a first geopolitical context in which the Maltese islands are part of a Larger Sicilian Archipelago. The Age of Rupture, in turn, sees the jurisdictional detachment of the smaller archipelago from the wider Kingdom of Sicily. It generates a de facto territorial rupture and subsequent creation of two politically independent archipelagos (the Sicilian Archipelago vis-à-vis the Maltese Archipelago). However, in accordance with our suggestion about ex post action for new archipelago identifications, we propose (as a third and final step) a renewed vision of a Sicilian-Maltese Archipelago through the constitution of an institutionalized European cross-border region. This region would be shaped by strategies and processes already sponsored elsewhere at the EU level, and it would allow the pursuit of joint policies developed within the framework of European territorial cohesion in its cross-border modality. Indeed, the choice of such a name would arise out of respect for both cultures and their diversity, having matured over more than 400 years of political separation. In this regard, we strongly agree with Pugh's argument, inspired by the work of Walcott (1998; ctd. in Pugh, 2013, p. 14): archipelagic visions and island movements are not sought as mere resurrections of the past but as the immanence of the contemporary present while "maturity assimilates the features of every ancestor."

To understand the proposal, we must firstly focus the argument on the direct territorial relations between the Sicilian autonomous region and the Maltese sovereign state as political actors in the same maritime cross-border area. As this research identified in the short-term analysis, national relations between Italy and Malta have been and continue to remain politically relevant in Mediterranean affairs. However, this has come at the detriment of formal relations between the two islands' governments due to their different political statuses. Some exceptions do exist, as in the case of the reestablishment of friendly relations between Italians and Maltese in the aftermath of the Second World War. These were officially celebrated through a cultural exchange sponsored by the Sicilian Region and involving Boy Scouts from the Sicilian town of Acireale and the national Maltese equivalent in 1947-1948 (Ardizzone, 2002, p. 281). Regardless, the differences in sovereignty ultimately hindered policymaking debate between the two islands.

This is precisely the reason why Malta's accession to the EU in 2004 represents both an important moment of rupture from previous sovereignty debates and an opportunity for the consolidation of archipelagic policies. In practical terms, it means that for the first time after centuries of separation both islands are again affiliated with a common political structure. 
Furthermore, the European framework welcomes the chance for multilevel governance relations between different territorial administrations, even in the atypical case between a region and a national government. Specifically, we refer to the policy of European Territorial Cooperation to be achieved through the INTERREG instrument. In its simplest definition, this involves special programmes and funding to be granted to private agents and public actors at different levels of government cooperating across national borders (INTERACT, 2018). Born out of the newly classified EU internal maritime frontier between Sicily and Malta, the cross-border Italy-Malta INTERREG programme was initiated in the very same year as Maltese accession. It effectively allowed for the institutionalization of joint INTERREG structures between the regional and national governments of the two islands. Over its 14 years of existence, the local programme has given birth to some interesting cooperation initiatives while also suffering from legal and administrative obstacles that limited its current effectiveness (Camonita, 2019). However, Sicily-Malta cross-border cooperation is still currently limited to the technical execution of the programme without deeper political dialogue. In the modern EU, this may correspond to more advanced policy agreements or even the establishment of a cross-border governance platform in the area. To quote a meaningful example, a recent investigation reported there to be 158 active cross-border organizations classified under the 'Euroregion' governance modality across virtually every other EU internal border (Durà et al., 2018).

The establishment of an INTERREG programme between the two territories may have been the initial spark reigniting institutional Sicilian-Maltese relations. However, it is here suggested that further action may be taken through employing European cross-border governance structures in the area. The usual tasks associated with their operations generally include common identity-building of a cross-border region, plus increased level of policy dialogue through involvement of public and private actors at multiple levels (local, supralocal, or regional). In our ex post conceptualization, the establishment of a Euroregional strategy pursuing archipelagic policies would constitute a highly beneficial focus on the common development of Sicily and Malta.

While the primary target of this research relates to methodological advances in the identification of archipelagos as described by island studies, the results of the analysis may constitute an initial roadmap for policymakers in the consolidation of a cross-border Euroregional strategy; one which could be discerned in the rediscovered Sicilian-Maltese Archipelago. The long-term analysis provides a clear basis for calling for joint territorial policies; the medium-term analysis holds the key to interpreting the cross-border identity roots of the two island populations; finally, the short-term analysis deals with the modern political opportunities for cooperation between a troubled autonomous region in search of a general strategy and a small but smart sovereign state facing issues of long-term sustainability.

As may be expected, we also acknowledge that cross-border cooperation practices will not be the only solution to all the archipelago's challenges. This will most likely be due to the persisting legal and administrative obstacles in the European processes of cooperation and the limited financial resources provided by European INTERREG programmes. Nevertheless, when assessing such a framework, we consider the added value that a joint platform of cross-border governance may bring to the two island territories. First and foremost, the political will to create a cross-border structure would hold great symbolic value towards committing the two islands to archipelagic visions. At the individual level, we envision a precious experience of political empowerment for Sicily through consolidating its 
external relations and developing them alongside a partner experienced in European strategies. Furthermore, such Europeanizing practices would be constantly pursued in a framework of increased efficiency and legality inspired by cooperation at the international level. For Malta, we appreciate the potential benefits that may be provided by the alignment of territorial and economic policies. They may be considered in terms of potential access to further natural and human resources, of which the Maltese are currently in need. Provided that the political classes may be convinced of such reconfigurations in policymaking, all arguments could justify negotiations leading to the establishment of a 'Sicilian-Maltese Archipelago Euroregion'.

\section{Conclusion}

This article represents an applied attempt at advancing the island studies debate in the field of island-to-island relations, archipelagos, and island movements. It does so by further developing the debate articulated by authors such as Stratford et al. (2011) and Pugh (2013). Beginning from their reasoning, we have identified two gaps in the specialized literature regarding practical methodologies in the application of archipelagic visions: a) an ex ante gap relative to the lack of a methodology for the classification of island movements' typologies; and b) an ex post vacuum in the strategy needed for bridging archipelagic conceptualizations with the institutional and policy fields of islands involved. Throughout the article, we responded to the ex ante issue by providing a new 'technology for un-islanding' based on the creation of a triple-level methodology of analysis for archipelagos. This was mainly based upon inspiration from the revived debate on Braudel's Longue Durée methodology and Pugh's definition of island movements. In turn, the ex post lack of policy strategies was filled by the opportunity, at least for the EU's islands, to benefit from strategic processes embedded in European territorial cohesion policies.

The methodological proposition has been filtered through the case study of the SicilyMalta cross-border maritime area. By applying our focus on the three historical levels, we have been able to define the traits of a Sicilian-Maltese Archipelago reality. These were defined by: a) a revived consideration on territorial matters regarding both islands (long-term); b) a classification of the typology of island movements between the two units during the alternation of their historical cycles (medium-term); and c) a further testing of the island movements' identification throughout a selected timeframe (1945-2018), acknowledging important features about the most recent historical, cultural, and psychological processes of each individual island (short-term). Furthermore, we also hinted at the potential opportunities for ex post application of archipelago visions to European islands and specifically to the Sicilian-Maltese case. By taking advantage of the European INTERREG instrument and political cross-border governance platforms such as the Euroregion, there is enough common ground to suggest the introduction of archipelagic elements in European cross-border islands' strategies.

While we believe we have successfully exploited the methodology for unravelling the features of the Sicilian-Maltese archipelago, we nonetheless consider the need for opening future lines of research. This call may be addressed as much to island studies scholars as to academics involved in European territorial cohesion and more specifically to cross-border cooperation in European island contexts. Indeed, there is still much work left to do for proponents of archipelagic visions. On the one hand, there is scope for further refining the three-durations methodology, the classification of island movements, and the application of 
the whole process to new archipelago cases. On the other hand, the suggestion proposed in crossing archipelagic ontologies and regional cross-border strategies could open a new trend for studying and observing cross-border cooperation across European islands. The compatibility between the two could be further tested in relation to the territorial competences and the instruments available to European units; the same could be proven regarding the political effects that an archipelagic vision would hold sway over island populations and institutions.

\section{Acknowledgments}

The author wishes to thank the three anonymous reviewers and two Editors of the Journal (Executive Editor Dr. Adam Grydehøj and Dr. Jonathan Pugh) for the extensive feedback and suggestions to this article which strongly helped to achieve a definitive version. A special mention also goes to Dr. Jamie D. Stacey for his commitment into a language and style revision. This work has been funded by an FPI Spanish grant scheme for predoctoral research (BES-2014-068387) associated to the COOP-RECOT II research project (CSO201345257-P "Territorial Cooperation in Spain and the EU: A selection of guiding experiences for Excellency and Innovation in the 2014-2020 period").

\section{References}

4cOffshore (2015). Malta-Sicily Interconnector. 4cOffshore website. https://www.4coffshore.com/news/interconnector-malta-sicily-icid67.html

Agnew, J. (2000). Italy's island other: Sicily's history in the modern Italian body politic. Emergences: Journal for the Study of Media \& Composite Cultures, 10(2), 301-311. https://doi.org/10.1080/713665814

Ardizzone, P. (2002). Studi maltesi: lotte per l'egemonia culturale e politica a Malta: aspetti linguistici ed istituzionali. In Salvadorini, V.A. (Ed.) Studi Mediterranei ed Extraeuropei (pp. 261-307). Pisa: Edistudio

Armitage, D., \& Guldi, J. (2015a). The return of the Longue Durée: an Anglo-American perspective. Annales HSS, 70(2), 219-247. https://doi.org/10.1353/ahs.2015.0033

Armitage, D., \& Guldi, J. (2015b). Pour une 'histoire ambitieuse'. Une réponse à nos critiques. Annales HSS, 70(2), 367-378. https://doi.org/10.1353/ahs.2015.0029

Armitage, D., \& Guldi, J. (2014). Going forward by looking back: the rise of the longue durée. In D. Armitage \& J. Guldi (Eds.) The History Manifesto (pp. 14-37). Cambridge:

Cambridge University Press. https://doi.org/10.15762/zh.2016.28

Baldacchino, G. (2018). Seizing history: development and non-climate change in Small Island Developing States. International Journal of Climate Change Strategies and Management, 10(2), 217-228. https://doi.org/10.1108/IJCCSM-02-2017-0037

Baldacchino, G. (2015). Lingering colonial outlier yet miniature continent: notes from the Sicilian Archipelago. Shima, 9(2), 89-102.

Blouet, B. (1997). The Story of Malta (6 ${ }^{\text {th }}$ Ed.). Valletta: Progress Press.

Bonanno, A. (2006). Insularity and isolation: Malta and Sicily in prehistory. In A. Bonanno \& P. Militello (Eds.) Malta in the Hybleans, the Hybleans in Malta: Proc. Int. Conference (pp. 27-38). Catania: Officina di Studi Medievali Catania. 
Bonanno, A., \& Militello, P. (Eds.) (2008). Malta in the Hybleans, the Hybleans in Malta. Palermo, Italy: Officina di Studi Medievali Palermo.

Braudel, F. (1972). The Mediterranean and the Mediterranean world in the age of Philip II. Vol. III. Oakland: University of California Press.

Briguglio L. (1995). Small island developing states and their economic vulnerabilities. World Development, 23, 1615-1632. https://doi.org/10.1016/0305-750X(95)00065-K

Camonita, F. (forthcoming 2019). Cross-border islands governance: a field analysis of the Italy-Malta Interreg Programme. In Dupeyron et al. (Eds.) Agents and structures in crossborder governance: Comparing North America and Europe in an era of border securitization. Toronto: University of Toronto Press. https://doi.org/10.3726/978-3-0352-6452-4/13

Canto Mayén, E. (2012). Un texto en tres duraciones : Braudel y El Mediterráneo. Temas Antropológicos, 34, 155-178

Cassar, C. (2000). A concise history of Malta. Msida: Mireva Publications.

Cassar, L.F., Conrad, E., \& Schembri, P.J. (2008). The Maltese archipelago. In I. Vogiatzakis, G. Pungetti, \& A.M. Mannion (Eds.) Mediterranean island landscapes: Natural and cultural approaches (pp. 297-322). Berlin: Springer Science \& Business Media. https://doi.org/10.1007/978-1-4020-5064-0 13

Castillo, D. (2005). The Maltese Cross: A strategic history of Malta. Santa Barbara, CA: Praeger.

Chandler, D., \& Pugh, J. (2018). Islands of relationality and resilience: The shifting stakes of the Anthropocene. Area, published ahead of print. https://doi.org/10.1111/area.12459.

Cordina, G., \& Farrugia, N. (2005). Measuring vulnerability: a methodological review and a refinement based on partner country and price volatility issues. Malta: Institute for Islands and Small States Studies, Occasional Papers, 4, 1-10.

Correnti, S. (2002). A short history of Sicily. Riga: Les Éditions Musae.

DeLoughrey, E. (2007). Routes and roots: navigating Caribbean and Pacific island literatures. Honolulu: University of Hawai'i Press.

DeLoughrey, E. (2001). The litany of islands, the rosary of archipelagoes: Caribbean \& Pacific archipelagraphy. Ariel: Review of International English Literature, 32(1), 21-51.

Deleuze, G. \& Guattari, F. (1986). Kafka: towards a minor literature. Minneapolis, MN: University of Minnesota Press.

Di Matteo, S. (2006). La Storia della Sicilia. Dalla preistoria ai nostri giorni. Palermo: Arbor.

Dodds, R., \& Kelman, I. (2008). How climate change is considered in sustainable tourism policies: A case of the Mediterranean islands of Malta and Mallorca. Tourism Review International, 12(1), 57-70. https://doi.org/10.3727/154427208785899920.

Durà, A., Camonita F., Berzi M. and Noferini, A. (2018). Euroregions, excellence and innovation across EU borders: a catalogue of good practices. Barcelona: Department of Geography (Universitat Autónoma de Barcelona).

EURISLES (2002). Off the coast of Europe: European construction and the problem of the islands. Islands Commission of the Conference of the Peripheral and Maritime Regions (CPMR). https://europeansmallislands.files.wordpress.com/2016/04/off-the-coast-ofeurope.pdf

EUROISLANDS (2013). The development of the islands-European islands and cohesion policy. ESPON. https://www.espon.eu/programme/projects/espon-2013/targeted- 
analyses/euroislands-development-islands-\%E2\%80\%93-european-islands

European Commission (2018a). Motorways of the sea. European Commission.

https://ec.europa.eu/transport/modes/maritime/motorways sea en

European Commission (2018b). Country Report Malta 2018. European Commission.

https://ec.europa.eu/info/sites/info/files/2018-european-semester-country-report-

malta-en.pdf

Goodwin, S. (2002). Malta, Mediterranean bridge. Westport: Bergin \& Garvey.

Hamel, P. (2011). Breve Storia della Società Siciliana 1790-1980. Palermo: Sellerio Editore.

Harwood, M. (2014). Malta in the European Union. London: Routledge.

Hau'ofa, E. (1993). Our sea of islands. In E. Waddell, V. Naidu \& E. Hau'ofa. (Eds.) A new oceania: rediscovering our sea of islands (pp. 2-16). Suva: University of the South Pacific.

INTERACT (2018). About Interreg. Interact. https://interreg.eu/about-interreg/

Italy-Malta INTERREG (2015). European Territorial Cooperation. Cross-Border Cooperation Programme 'INTERREG V-A Italy-Malta'. Italy-Malta INTERREG. http://www.italiamalta.eu/component/option,com docman/task, doc download/gid, 588/Itemid,99999999/lang,it/

Kelman, I. (2019). Islands of vulnerability and resilience: manufactured stereotypes? Area, published ahead of print . https://doi.org/10.1111/area.12457

Leonardi, R. (2016). Perché la Sicilia non riesce a usare i fondi strutturali per decollare economicamente. In G. Armao \& M. Saija (Eds.) Settant'anni di autonomia siciliana 1946-2016 (pp. 271-295). Palermo: Rubbettino Editore.

Lewis, M.W., \& Wigen, K.E. (1997) The myth of continents: a critique of metageography, Berkeley: University of California Press. https://doi.org/10.1086/ahr/103.4.1209

Lopasic, A. (2001). Mediterranean Islands: a concept. Coll. Antropol., 25(1), 363-370.

Mack Smith, D., \& Finley, M.I. (1968). A history of Sicily. New York: Viking Press.

Menighetti, R., \& Nicastro, F. (2002). History of autonomous Sicily (1947-2001). Mineola: Legas.

Moncada, S., Camilleri, M., Formosa, S., \& Galea, R.(2010). From incremental to comprehensive: towards island-friendly European Union policymaking, Island Studies Journal, 5(1), 61-88.

Murray Ballou, M. (1893). The story of Malta (I-II). New York: Houghton, Mifflin \& Co.

Musotto, F. (2007). Report on the islands and natural and economic constraints in the context of the regional policy. A6-0044/2007. Committee on Regional Development of the European Parliament.

http://www.europarl.europa.eu/sidesSearch/search.do?type $=$ REPOR T\&language $=\mathrm{E}$ N\&term $=6 \&$ author $=4471$

Nicholls, R.J., \& Hoozemans, F.M.J. (1996) The Mediterranean: vulnerability to coastal implications of climate change. Ocean \& Coastal Management, 31(2-3), 105-132. https://doi.org/10.1016/S0964-5691(96)00037-3

Noferini A., Berzi, M., Camonita, F., \& Durà, A. (2019). Cross-border cooperation in the EU: Euroregions amid multilevel governance and re-territorialization. European Planning Studies, forthcoming.

Papayannis, T., \& Sorotou, A. (2008). Cultural landscapes of Mediterranean Islands. In A.M. Vogiatzakis G. Pungetti and A.M. Mannion (Eds.) Mediterranean island landscapes: 
natural and cultural approaches (pp. 82-99). Berlin: Springer Science \& Business Media. https://doi.org/10.1007/978-1-4020-5064-0 5

Popescu, G. (2008). The conflicting logics of cross-border reterritorialization: geopolitics of Euroregions in Eastern Europe. Political Geography, 27(4), 418-438.

https://doi.org/10.1016/j.polgeo.2008.03.002

Pugh, J. (2013). Island movements: Thinking with the archipelago. Island Studies Journal, $8(1), 9-24$.

Pugliese, J. (2011) Review of S. Perera, Australia and the insular imagination: beaches, borders, boats and bodies, Continuum, 25(1), 134137.https://doi.org/10.1080/10304312.2011.538038.

Renda, F. (2003). Storia della Sicilia dalle origini ai giorni nostri. Palermo: Sellerio Editore. https://doi.org/10.2307/40069710

Schneider, J., \& Schneider, P.T. (1976). Culture and political economy in western Sicily. Cambridge: Academic Press.

Sengupta, S. (2004). Notes for keynote conversation. www2.asialink.unimelb.edu.au/arts/projects/forum2004/ssengupta.pdf.

Stratford, E., Godfrey, B., Mcmahon, E., Farbotko, C., \&Harwood, A. (2011). Envisioning the archipelago. Island Studies Journal, 6(2), 113-130.

The Independent (2015). What's wrong with the Sicilian? The Independent (Malta), 3 September. http://www.independent.com.mt/articles/2015-09-03/businessnews/What-s-wrong-with-the-Sicilians-6736141520

Walcott, D. (1998). What the twilight says: Essays. Boston, MA: Faber \& Faber.

Warrington, E., \& Milne, D. (2018). Governance. In G. Baldacchino (Ed.) The Routledge international handbook of island studies (Ch. 8, Ebk). New York: Routledge. 